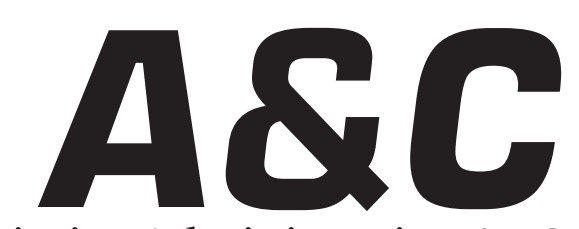

Revista de Direito Administrativo \& Constitucional

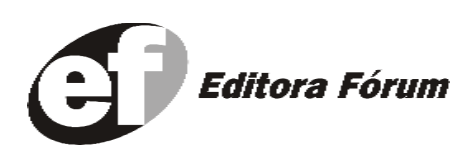

A\&C R. de Dir. Administrativo e Constitucional, Belo Horizonte, ano 4, n.16, p. 1-255, abr.jun. 2004 


\section{A\&C REVISTA DE DIREITO ADMINISTRATIVO E CONSTITUCIONAL}

\section{IPDA}

Instituto Paranaense

de Direito Administrativo

Direção Geral

Romeu Felipe Bacellar Filho

Direção Editorial

Paulo Roberto Ferreira Motta

Direção Executiva

Emerson Gabardo

Conselho de Redação

Edgar Chiuratto Guimarães

Adriana da Costa Ricardo Schier

Célio Heitor Guimarães

Conselho Editorial

\section{Adilson Abreu Dallari Lúcia Valle Figueiredo}

Alice Gonzáles Borges Manoel de Oliveira Franco Sobrinho

Carlos Ari Sundfeld (in memoriam)

Carlos Ayres Britto Marçal Justen Filho

Carlos Delpiazzo Marcelo Figueiredo

Cármen Lúcia Antunes Rocha Márcio Cammarosano

Celso Antônio Bandeira de Mello Maria Cristina Cesar de Oliveira

Clèmerson Merlin Clève Nelson Figueiredo

Clóvis Beznos Odilon Borges Junior

Enrique Silva Cimma Pascual Caiella

Eros Roberto Grau Paulo Eduardo Garrido Modesto

Fabrício Motta Paulo Henrique Blasi

Guilhermo Andrés Muñoz Paulo Neves de Carvalho

Jorge Luís Salomoni Paulo Ricardo Schier

José Carlos Abraão Pedro Paulo de Almeida Dutra

José Eduardo Martins Cardoso Regina Maria Macedo Nery Ferrari

José Luís Said Rogério Gesta Leal

José Mario Serrate Paz Rolando Pantoja Bauzá

Juan Pablo Cajarville Peruffo Sérgio Ferraz

Juarez Freitas Valmir Pontes Filho

Julio Rodolfo Comadira Yara Stropa

Luís Enrique Chase Plate Weida Zancaner

Os conceitos emitidos em trabalhos assinados são de responsabilidade de seus autores, que gozam de inteira liberdade de opinião. e-mail para remessa de artigos, pareceres e contribuições: e.gab.@uol.com.br

ou conselho@editoraforum.com.br Endereço para envio de contribuições: Editora Fórum

Revista A\&C, Av. Afonso Pena, 2770, 15\%16ª andar, Funcionários, CEP 30130-007 - Belo Horizonte - MG

A\&C Revista de Direito Administrativo e Constitucional. Ano 3, n. 11, jan./mar. 2003. Belo Horizonte: Fórum, 2003.

Trimestral

ano 1, n.1, 1999 até ano 2, n.10, 2002 publicada pela Editora Juruá em Curitiba

ISSN: $1516-3210$

1. Direito Administrativo. 2. Direito Constitucional. I. Fórum.

CDD: 342 CDU: 33.342
Editor responsável: Luis Cláudio Rodrigues Ferreira Projeto gráfico: Luis Alberto Pimenta

Diagramação: Anderson Pimenta

Revisora: Olga M. A. Sousa

Pesquisa jurídica: Fátima Ribeiro - OAB/MG 74868 Bibliotecária: Nilcéia Lage de Medeiros -

CRB 1545/MG - 6 a região

(C) Editora Fórum Ltda 2004.

Proibida a reprodução total ou parcial desta obra, por qualquer meio eletrônico, inclusive por processos xerográficos, sem autorização expressa do editor.

Distribuída em todo o território nacional

Assinaturas e comercialização:

Editora Fórum, Av. Afonso Pena, 2770, 15-16 andar, Funcionários, CEP 30130-007 - Belo Horizonte - MG Tel.: (31) 2121-4900 - 0800 704-3737

e-mail: editoraforum@editoraforum.com.br site: www.editoraforum.com.br 


\title{
O IPTU Progressivo como Instrumento de Efetivação da Função Social da Cidade no Brasil ${ }^{1}$
}

\author{
Rogério Gesta Leal \\ Doutor em Direito. Professor Titular da Universidade de Santa Cruz do Sul. Coordenador do \\ Programa de Mestrado em Direito desta Universidade. Desembargador do Tribunal de Justiça \\ do Estado do Rio Grande do Sul
}

Sumário: 1 Notas introdutórias - 2 A natureza jurídica e política do IPTU no sistema jurídico brasileiro - 3 Novos cenários normativos e hermenêuticos atinentes ao IPTU no Brasil - 4 A experiência do Município de Porto Alegre na Gestão do IPTU: aspectos de legalidade - 5 Considerações finais - Referências

\section{Notas introdutórias}

O presente trabalho foi preparado para o curso de desenvolvimento profissional sobre o imposto à propriedade imobiliária, desenvolvido pelo Lincoln Institute of Land Policy, em Boston, EUA, nos dias 19 a 24 de abril de 2004. Em face das particularidades práticas dos workshops desenvolvidos neste evento, a abordagem que faremos do tema proposto estará focada notadamente para um enfrentamento tópico (pontual) do Imposto Predial e Territorial Urbano (IPTU) no Brasil, em suas matizes constitucionais e infraconstitucionais, fiscais e extrafiscais.

Para tanto, vamos, num primeiro momento, localizar o IPTU no sistema jurídico pátrio, para em seguida tensionar suas dimensões políticas e jurídicas consectárias.

Num segundo momento, pretendemos verificar de que forma os novos cenários normativos no Brasil, a partir notadamente da Emenda Constitucional no 29/2000 e do Estatuto da Cidade, estão a redefinir o IPTU no âmbito de sua progressividade.

Ao final, vamos analisar um caso concreto administrativo e jurisdicional envolvendo o tratamento administrativo e tributário do IPTU de uma das mais importantes capitais do país, Porto Alegre, no Rio Grande do Sul, Brasil, destacando as dimensões políticas de inclusão social e concretização do conceito constitucional de função social da cidade.

\section{A natureza jurídica e política do IPTU no sistema jurídico}

\footnotetext{
1 Trabalho apresentado no Curso sobre Gestão da Terra Urbana e Rural, ocorrido nos dias 19 a 24 de abril de 2004, no Lincoln Institute, em Boston, EUA.
}

A \& C R. de Dir. Administrativo e Constitucional, Belo Horizonte, ano 4, n. 16, p. 107-123, abr./jun. 2004 


\section{brasileiro}

O conceito de tributo, no sistema jurídico brasileiro, nos é dado pelos termos de lei constitucional e infraconstitucional (Código Tributário Nacional), entendido, neste particular, como toda prestação pecuniária compulsória, instituída em lei e cobrada mediante atividade administrativa plenamente vinculada. ${ }^{2}$ Em termos de especificidades de tributos, contamos tradicionalmente com cinco modalidades de tributos, a saber: os impostos, as taxas, as contribuições de melhoria, as contribuições especiais e os empréstimos compulsórios. ${ }^{3}$

As contribuições especiais, por sua vez, definidas nos termos dos arts.149 e 195, ambos da Constituição Federal de 1988, dividem-se em contribuições sociais (que se subdividem em contribuições de intervenção no domínio econômico e contribuições do interesse de categorias profissionais ou econômicas), e contribuições de seguridade social. ${ }^{4}$

Veja-se que, ainda em termos conceituais, o imposto é o tributo cuja obrigação tem por fato gerador uma situação independente de qualquer atividade estatal específica, relativa ao contribuinte. Não depende, portanto, de uma atividade vinculada. Já a taxa, apresenta-se como tributo que tem como fato gerador o exercício regular do poder de polícia ou a utilização, efetiva ou potencial, de serviço público específico e divisível, prestado ao contribuinte. A contribuição de melhoria, por sua vez, configura-se como tributo cuja obrigação tem como fato gerador a valorização de imóvel decorrente de obra pública.

No que tange às funções do plexo tributário para o país, a doutrina tem insistido no fato de que os tributos possuem múltiplos fundamentos, a saber: (a) fiscal, quando seu principal objetivo é a arrecadação de recursos financeiros para o Estado; (b) extrafiscal, quando seu objetivo principal é a interferência no domínio econômico, buscando um efeito diverso da simples arrecadação de recursos financeiros; (c) parafiscal, quando o seu objetivo é a arrecadação de recursos para o custeio de atividades que, em princípio, não integram funções próprias do Estado, mas este as desenvolve através de entidades específicas. $^{5}$

Ao lado destes fundamentos, podemos afirmar de forma consensual

que neste mesmo sistema jurídico os tributos contam com previsões Para fins de uma conceituação mais acadêmica, ver o texto de COELHO, Sacha Calmon Navarro. Comentários à Constituição de 1988: sistema tributário. Rio de Janeiro: Forense, 2000, p. 35 et seq.

${ }^{3}$ Nos termos do art. 148, CF/88. A despeito do estatuto constitucional nominá-la de tributo, o Supremo Tribunal Federal durante um certo tempo entendeu que não se trata de tributo, mas de um contrato coativo, orientação esta consagrada na sua súmula 418.

${ }^{4}$ Consoante definições estabelecidas a partir do art. 145, da Constituição Federal de 1988.

${ }^{5}$ Neste sentido, ver o texto de CARVALHO, Paulo de Barros. Curso de Direito Tributário. São Paulo: Saraiva, 2001.

A \& C R. de Dir. Administrativo e Constitucional, Belo Horizonte, ano 4, n. 16, p. 107-123, abr./jun. 2004 
normativas de ordem principiológica e regratória, tais como: (a) o da certeza do direito, que visa principalmente a segurança do indivíduo, pois elege a certeza como postulado indispensável para a convivência social organizada; ele é implícito e todas as diretrizes do ordenamento operam no sentido de realizá-lo; (b) o da segurança jurídica, objetivando dar tranqüilidade aos cidadãos, abrindo espaços para o planejamento de ações futuras, cuja disciplina jurídica conhecem, confiantes que estão no modo pelo qual a aplicação das normas do direito se realiza; (c) o da igualdade, contido no art. $5^{\circ}$, I, da $\mathrm{CF} / 88$, buscando assegurar um tratamento isonômico a qualquer cidadão, voltado com mais ênfase ao legislador, pois ele deverá ter em mente tal referência; (d) o dos direitos e garantias fundamentais, haja vista que são os termos nucleares de todo o sistema. ${ }^{6}$

Observando tais princípios e regras é que a norma jurídica que trata de qualquer tipo de tributo - e que na doutrina especializada tem sido chamada de regra matriz tributária do fenômeno da incidência - necessariamente terá que estabelecer o critério material, espacial e temporal presentes na hipótese da regra-matriz e, também, o sujeito ativo e passivo, assim como a base de cálculo e o valor da alíquota presentes no conseqüente da norma instituidora do tributo. ${ }^{7}$

Por certo que em nível geral e mesmo especial para o Direito Tributário, o princípio da legalidade, localizado no inciso II, do art. $5^{\circ}$, da $\mathrm{CF} / 88$, encontra-se no centro neural do sistema jurídico, ratificado que está nas disposições do art. 150, I, da CF/88, ao referir que é vedado... exigir ou aumentar tributo sem lei que o estabeleça.

Por tais razões, tem-se sustentado que a essência do direito tributário - respeitados os postulados fixados pela própria constituição — reside na integral submissão do poder estatal à rule of law. A lei, enquanto manifestação estatal estritamente ajustada aos postulados subordinantes do texto consubstanciado na Carta da República, qualifica-se como decisivo instrumento de garantia constitucional dos contribuintes contra eventuais excessos dos poderes instituídos em matéria tributária. ${ }^{8}$

Assim é que a Constituição Federal tem outorgado competência às entidades federativas para que exercitem suas políticas tributárias,

\footnotetext{
${ }^{6}$ Como quer CARVALHO, Paulo de Barros. Direito Tributário. São Paulo: Saraiva, 2001, p. 39.

${ }^{7}$ Consoante o trabalho já clássico de BALEEIRO, Aliomar. Direito Tributário Brasileiro. Rio de Janeiro: Forense, 1999, p. 41 et seq.

${ }^{8}$ Neste sentido ver o texto de XAVIER, Alberto. Os Princípios da Legalidade e da Tipicidade da Tributação. São Paulo: Revista dos Tribunais, 1998, p. 84.
} 
observados os limites dados pelo sistema jurídico como um todo, e principalmente o constitucional. Neste ponto, atente-se à bem lançada advertência de Carrazza, ao referir que:

De fato, entre nós, a força tributante estatal não atua livremente, mas dentro dos limites do direito positivo. Como veremos em seguida, cada uma das pessoas políticas não possui, em nosso País, poder tributário (manifestação do ius imperium do Estado), mas competência tributária (manifestação da autonomia da pessoa política e, assim, sujeita ao ordenamento jurídico constitucional). A competência tributária subordina-se às normas constitucionais, que, como é pacífico, são de graus superior às de nível legal, que prevêem as concretas obrigações tributárias. ${ }^{9}$

Em outras palavras, temos que a Constituição Federal delimita a competência tributária de todos os entes políticos, e estes, para instituírem os tributos de sua competência, devem editar leis que prevejam os elementos essenciais da norma jurídico-tributária competente. Cada ente tributante deve, pois, instituir a regra matriz de incidência tributária.

Decorrência disto é que só ao depois de criada a norma tributária competente de cada entidade federativa é que poderá o tributo ser cobrado do sujeito passivo. De tal competência decorre igualmente os poderes institucionais de majorar a alíquota dos tributos, diminuí-la, conceder isenções, conceder parcelamentos, tudo nos termos das normativas consectárias, especialmente as constitucionais, aqui tomando relevo as limitações ao poder de tributar, tais como o do não-confisco, o princípio da capacidade contributiva, da legalidade e da anterioridade. ${ }^{10}$

Em nível de IPTU, o plano normativo constitucional vigente estabelece, em seu art. 156, parágrafo $1^{\circ}$, previa, em sua redação original, que o imposto predial e territorial urbano poderia ser progressivo, no termos de lei municipal, de forma a assegurar o cumprimento da função social da propriedade. A partir deste dispositivo, um segmento da doutrina nacional e mesmo da jurisprudência insistia na tese de que a progressividade no IPTU somente poderia ser aquela prevista no art. $182,{ }^{11}$ parágrafo $4^{\circ} \mathrm{da}$ Constituição Federal. ${ }^{12}$

${ }^{9}$ CARRAZA, Roque Antonio. Curso de Direito Constitucional Tributário. São Paulo: Malheiros, 2001, p. 53. Adverte o autor ainda que: Em boa técnica, não se deve dizer que as pessoas políticas têm, no Brasil, poder tributário. Poder tributário tinha a Assembléia Nacional Constituinte, que era soberana. Ela, realmente, tudo podia, inclusive em matéria tributária. A partir do momento, porém, em que foi promulgada a Constituição Federal, o poder tributário retornou ao povo (detentor da soberania). O que passou a existir, em seu lugar, foram as competências tributárias, que a mesma Constituição Federal repartiu entre a União, os Estadosmembros, os Municípios e o Distrito Federal.

${ }^{10}$ Ver o trabalho de CONTI, José Maurício. Princípios Tributários da Capacidade Contributiva e da Progressividade. São Paulo: Dialética, 1997. 
Reforçava este argumento uma interpretação reducionista que estas mesmas correntes imprimiam ao art. 145, da CF/88, afirmando que, em seu parágrafo primeiro, havia a previsão de que, sempre que possível, os impostos teriam caráter pessoal e seriam graduados segundo a capacidade econômica do contribuinte, facultado à administração tributária, especialmente para conferir efetividade a esses objetivos, identificar, respeitados os direitos individuais e nos termos da lei, o patrimônio, os rendimentos e as atividades econômicas do contribuinte.

Tais enunciados nos remetem, inexoravelmente, para um outro conjunto de conceitos que precisam ser esclarecidos aqui, quais sejam, os atinentes ao caráter pessoal ou real dos impostos. Em termos doutrinários, tem-se que os impostos pessoais são aqueles que visam levar em consideração certos aspectos juridicamente qualificados dos possíveis sujeitos passivos, recaindo essencialmente sobre sua pessoa, mediante as características financeiras concernentes a cada indivíduo. ${ }^{13}$ Nas palavras de Baleeiro:

os impostos pessoais, ou subjetivos, são regulados por critérios que contemplam a individualidade do contribuinte. As condições personalíssimas deste são elementos que se integram na formação do fato gerador e determinam variações para mais, ou menos, na fixação do quantum a ser reclamado pelo fisco. ${ }^{14}$

De outro lado, tem-se como reais, impessoais ou objetivos, aqueles impostos fundados sobre a materialidade da coisa tributável, inexistindo como parâmetro mediador a condição do sujeito passivo. Para Bernardo Ribeiro de Moraes, imposto real é aquele que:

é calculado sem atender as condições pessoais do contribuinte, ou melhor, ignorando por completo a situação individual do contribuinte (o imposto grava uma riqueza dada ou uma situação da mesma maneira, qualquer que seja o sujeito passivo). Os impostos reais gravam o contribuinte tendo em vista apenas a matéria tributável, segundo seus caracteres objetivos específicos, independentemente das condições econômicas, jurídicas, pessoais ou de família, relativas ao contribuinte.

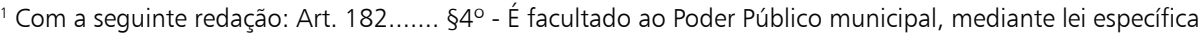
para área incluída no plano diretor, exigir, nos termos da lei federal, do proprietário do solo urbano não edificado, subutilizado ou não utilizado, que promova seu adequado aproveitamento, sob pena, sucessi vamente, de: II - imposto sobre a propriedade predial e territorial urbana progressivo no tempo.

${ }^{12}$ Ver os trabalhos de FURLAN, Valéria C. P. Imposto Predial e Territorial Urbano. São Paulo: Malheiros, 1998; ICHIHARA, Yoshiaki. O Princípio da Progressividade e suas Implicações no IPTU. Revista de Direito Tributário São Paulo, n. 81, 2000. Da mesma forma a jurisprudência dominante: STF - RE $248892-2^{a}$ T. - Rel. Min. Maurício Corrêa - DJU 31 mar. 2000, p. 63; TJMG - AC 000.202.005-5/00 - 1ª C.Cív. - Rel. Des. Antônio Hélio Silva - J. 08.02.2001.

${ }^{13}$ Ver o texto de NASCIMENTO, Carlos Valder. A Questão da Progressividade do IPTU. Revista dos Tribunais, no 8, n. 34, p. 69-80.

14 BALEEIRO, Aliomar. Direito Tributário Brasileiro. Rio de Janeiro: Forense, 1999, p. 73.
} 
A alíquota tributária é fixada exclusivamente em função apenas das circunstancias materiais da situação de fato prevista em lei. ${ }^{15}$

No que tange à expressão sempre que possível, ela limitaria a progressividade fiscal aos impostos denominados "pessoais", sendo impossível aplicá-la aos impostos "reais", caso do IPTU. Por tais razões, revelar-se-ia impraticável a aplicação de alíquota progressiva no IPTU, exceto aquela prevista no parágrafo $1^{\circ}$, do art. 156 , em sua redação original. ${ }^{16}$

Vai nesta direção a opinião de boa parte da doutrina especializada, como a de Hugo de Brito Machado:

Não temos dúvida em afirmar que o sentido da cláusula sempre que possível contida no art. 145 , par. $1^{\circ}$, da Constituição Federal, é o de permitir a existência de impostos sem caráter pessoal, e não o de permitir imposto que não seja graduado segundo a capacidade econômica do contribuinte. ${ }^{17}$

Em meio a este debate, há uma problemática conceitual que está subjacente, qual seja, a que envolve dois institutos tributários distintos, o da progressividade fiscal e o da progressividade extrafiscal. O primeiro, vem determinado pela capacidade econômica do contribuinte, imprimindo sentido objetivo à máxima de tratar os desiguais de forma desigual, na medida de suas desigualdades (princípio da igualdade e da isonomia), além, por óbvio, de servir à obtenção de receitas financeiras ao erário público. Já o segundo instituto (o da progressividade extrafiscal), opera a partir de um paradigma exógeno ao do ordenamento jurídico tributário propriamente dito, eis que se vale de uma alíquota maior sobre o bem jurídico tributado, ultrapassando os fins meramente arrecadatórios, para alcançar outros que extrapolam a esfera individual ou estatal, para atingir metas e políticas públicas sociais, como o de induzir o adequado uso da propriedade urbana pelo proprietário do imóvel, a fim de alcançar a função social da cidade e mesmo da propriedade. ${ }^{18}$

\footnotetext{
${ }^{15}$ MORAES, Bernardo Ribeiro. Compêndio de Direito Tributário. Rio de Janeiro: Forense, 2002, v. 1, p. 441.

${ }^{16}$ Este é um falso argumento, eis que na situação dos impostos reais, a lei elege um fato como hipótese de incidência do tributo, o que afasta da hipótese de incidência quaisquer considerações em relação às qualida des pessoais do sujeito passivo. No entanto, isso não significa que o bem que pertence ao sujeito passivo evidencie - necessariamente - equivalência de riqueza, mas tão somente que na instituição do tributo sua condição pessoal não é valorada. Por tais razões, é possível dizer que a expressão "sempre que possível" referese aos impostos diretos e indiretos, haja vista a impossibilidade de se graduar a capacidade contributiva de impostos indiretos, assim como dos impostos fixos.

${ }^{17}$ MACHADO, Hugo de Brito. Curso de Direito Tributário. São Paulo: Malheiros, 2001, p. 92.
} 
Ora, salvo melhor juízo, e como vimos há pouco, não são todos os tributos que se harmonizam com o princípio da capacidade contributiva e conseqüentemente ao da progressividade, pois suas essências não possibilitam tal desatino. Nesta perspectiva doutrinária e jurisprudencial recém referida, é o caso dos impostos reais, que pelas suas particularidades impares não condizem com a graduação de suas alíquotas justamente pela impossibilidade de se mensurar exatamente a verdadeira capacidade contributiva de seu sujeito passivo.

É novamente Baleeiro que vem ratificar tal entendimento, ao dizer que:

Em regra geral, só os impostos pessoais se ajustam adequadamente à aplicação de critérios progressivos medidos pela capacidade contributiva, se bem que esta se possa presumir da natureza, valor e aplicação específica de determinada coisa, no sentido de que a possui, compra ou prefere o indivíduo de maiores recursos econômicos. Mas imposto sobre coisa, em princípio, exclui, por exemplo, a progressividade em atenção à pessoa, salvo casos de aplicação extrafiscal. ${ }^{19}$

Desta forma, a progressividade do IPTU, só poderia ocorrer em termos extrafiscais e nos limites do art. 182, da CF/88, consoante pacificação jurisprudencial provocada pelo Supremo Tribunal Federal, nos autos do Recurso Extraordinário no 153.771-0/MG - (Tribunal Pleno). Neste julgamento, deliberou seu posicionamento acerca da progressividade fiscal do IPTU, a partir do que as graduações fiscais de alíquotas foram rechaçadas e reiteradamente julgadas inconstitucionais em todo o país.

Por sua vez, o entendimento firmado pelo STF expressou-se no sentido de que a progressividade expressa no texto original do art 156 , $\S 1^{\circ}$, da $\mathrm{CF} / 88$, estava ligada umbilicalmente à progressividade temporal (extrafiscal) constante do art. $182, \S 4^{\circ}$, pertinente ao cumprimento da função social da propriedade:

No sistema tributário nacional é o IPTU inequivocamente um imposto real. Sob o império da atual Constituição, não é admitida a progressividade fiscal do IPTU, quer com base exclusivamente no seu art. $145, \S 1^{\circ}$, porque esse imposto tem caráter real que é incompatível com a progressividade decorrente da capacidade econômica do contribuinte, quer com arrimo na conjugação desse dispositivo constitucional (genérico) com o art. $156, \S 1^{\circ}$ (específico). A interpretação sistemática da Constituição conduz inequivocamente à conclusão de que o IPTU com finalidade extrafiscal a que alude o inciso II do $\$ 4^{\circ}$ do artigo 182 é a explicitação especificada, inclusive com limitação temporal, do IPTU com fina-

\footnotetext{
${ }^{18}$ Ver o trabalho de NUNES, Vidal Serrano. Direito Constitucional Tributário. São Paulo: Didática Paulista, 1990, p. 64 et seq.

19 BALEEIRO, Aliomar, op. cit., p. 82.
}

A \& C R. de Dir. Administrativo e Constitucional, Belo Horizonte, ano 4, n. 16, p. 107-123, abr./jun. 2004 
lidade extrafiscal aludido no art. 156, $\S 1^{\circ}$. Portanto, é inconstitucional qualquer progressividade, em se tratando de IPTU, que não atenda exclusivamente ao disposto no artigo 182, ambos da Constituição Federal. Recurso Extraordinário conhecido e provido, declarando-se inconstitucional o subitem 2.2.3 do setor II da Tabela III da Lei 5.641, de 22.12.1989, no município de Belo Horizonte. ${ }^{20}$

Este cenário de debates vai se modificar drasticamente a partir da edição da Emenda Constitucional no 29/2000 e mesmo do Estatuto da Cidade. Passemos às suas avaliações.

\section{Novos cenários normativos e hermenêuticos atinentes ao IPTU no Brasil}

Os comportamentos políticos e normativos do Estado brasileiro a partir da Constituição brasileira de 1988, como já referimos, estiveram autorizados, dentre outras coisas e para o que interessa nesta nossa abordagem, dirigidos à concretização dos direitos e garantias fundamentais, dentre os quais podemos destacar, por oportuno, a ampliação da igualdade substancial dentre seus cidadãos, eis que ela diz respeito diretamente para com a dignidade da pessoa humana. Esta igualdade substancial, além de sua dimensão humanística, possui concretamente uma acepção econômica, pois condizente com as possibilidades de inclusão social em termos de poder aquisitivo à aquisição do mínimo existencial. ${ }^{21}$

Na mesma direção temos, em nível de Direito Tributário no Estado Democrático de Direito, a orientação de que o tributo deixe de ser apenas uma fonte de renda e passe a ser um instrumento de realização da justiça. A igualdade no tratamento tributário deixa de ser apenas formal passando a ser materialmente um instrumento de redistribuição de riquezas. ${ }^{22}$

É neste diapasão que um princípio tributário se torna muito caro ao novo Estado constitucional brasileiro, a saber, o da capacidade contributiva, eis que visa propiciar a realização da justiça fiscal, onerando aqueles que evidenciem maior capacidade contributiva, aro mesmo tempo qua que 589), de competência dos municípios, firmando jurisprudência (RE.153.771-MG e RE.199.281-6 SP), tendo em conta o entendimento de que o IPTU é imposto real e, assim sendo, sob o império da atual Constituição, não é admitida a sua progressividade fiscal, quer com base exclusivamente no seu art. 145, $\S 1^{\circ}$, porque esse imposto tem caráter real, que é incompatível com a progressividade decorrente da capacidade econômica do contribuinte, quer com arrimo na conjugação desse dispositivo constitucional (genérico) com o art. 156, $§ 1^{\circ}$ (específico), do mesmo Estatuto Constitucional.

${ }^{21}$ Ver o trabalho de BALLEIRO, Aliomar. Limitações Constitucionais ao Poder de Tributar. Atual. por Mizabel Abreu Machado Derzi. Rio de Janeiro: Forense, 1997, p. 530 et seq. Na mesma direção o clássico trabalho de ATALIBA, Geraldo. Derechos Humanos y Tributación. In: PRIMERAS JORNADAS INTERNACIONALES DE TRIBUTACIÓN Y DERECHOS HUMANOS. Lima: Asociación Internacional de Tributación y Derechos Humanos, 1990, p.15 et seq.

22 GRUPENMACHER, Betina Treiger. Tributação e Direitos Fundamentais. In: Tributos e Direitos Fundamentais. São Paulo: Dialética, 2004, p. 15. 
desonerando a renda utilizada para fazer frente às demandas necessárias à vida digna anteriormente referida como escopo fundante da República. Nas palavras de Regina Costa, este princípio da capacidade contributiva afigura-se como um desdobramento do princípio da igualdade ou a de que é a manifestação ou aplicação deste no campo tributário. ${ }^{23}$

Na feliz expressão de Delgado, não podemos esquecer que o tributo não é cobrado para atender os interesses e as necessidades do Estado, mas possui destinação específica, a saber, a de servir como instrumento concretizador da satisfação das exigências materiais e imateriais dos componentes da textura social, fortalecendo, desta forma, a cidadania e a valorização da dignidade humana em sua acepção maior. ${ }^{24}$

Em outras palavras:

A validação finalística do tributo é abrangente. Encontra-se obrigado ao cumprimento de todos os objetivos constitucionais, todos voltados mais para o bem-estar da sociedade do que o do próprio Estado como instituição. Essa concepção exige que se afaste o entendimento do que o Direito Tributário deva ser estudado de modo compartimentado e obedecendo, apenas, aos seus princípios específicos, quer de ordem constitucional, quer situados no campo da legislação ordinária. ${ }^{25}$

Em face destas considerações, resta claro que um dos aspectos essenciais da atividade tributária, pois, está conectado à sua finalidade extrafiscal, na medida em que deve perseguir objetivos mais amplos e diversos do que os meramente fiscais, contribuindo para o ajustamento das condições materiais do mercado e da economia em face dos desafios e compromissos sociais existentes.

No dizer de Botelho, a tributação contemporânea não pode mais ficar adstrita a meras questões orçamentárias e fiscais dos poderes públicos, eis que se afigura como um dos principais mecanismos de repartição de riqueza e desenvolvimento econômico, contribuindo à inclusão social da cidadania como um todo. ${ }^{26}$

Num sistema jurídico com este desenho constitucional complexo e multifacetado, o perfil de intérprete e aplicador da norma jurídica tributária

\footnotetext{
${ }^{23}$ COSTA, Regina Helena. Princípio da Capacidade Contributiva. São Paulo: Malheiros, 1998, p. 40. Em excelente trabalho de dissertação, Marciano Buffon, registra sobre o tema que o princípio da capacidade contributiva pode ser entendido como corolário da justiça fiscal, posto que a carga tributária é repartida de acordo com a possibilidade de cada indivíduo de suportá-la. BUFFON, Marciano. O Princípio da Progressividade Tributária na Constituição Federal de 1988. São Paulo: Memória Jurídica, 2003, p. 70.

${ }^{24}$ DELGADO, José Augusto. A Interpretação Contemporânea do Direito Tributário e os Princípios da Valorização da Dignidade Humana e da Cidadania. In: Tributos e Direitos Fundamentais. São Paulo: Dialética, 2004, p. 156.

${ }^{25}$ Op. cit., p. 157. Refere autor, com o que concordamos, que a interpretação das normas de Direito Tributário

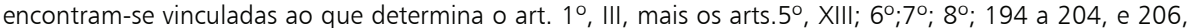
todos da Constituição Federal de 1988.
} 
precisa rever os indicadores explicitados nos arts.107, 108 e seguintes, do Código Tributário Nacional, no sentido de dar-lhes uma adequação/ conformidade constitucional, e isto porque, adotando a dicção de Eros Grau:

Embora o intérprete autêntico, no Direito Tributário, encontre-se mais vinculado ao princípio da legalidade estrita, não o afasta da regra de que a norma é produzida pelo intérprete autêntico e produzida não apenas a partir de elementos que se desprendem do texto (mundo do dever-ser), mas também a partir de elementos do caso ao qual será aplicada, isto é, a partir de elementos da realidade (mundo do ser). ${ }^{27}$

É a realidade brasileira atual, compreendida a partir do que se pretende da República Constitucional e Democrática de Direito, que deve informar as possibilidades de interpretação e aplicação da norma tributária e de suas funções fiscais e sociais.

Com tal horizonte é que se produziu, ao menos em termos formais, mais dois instrumentos de matriz constitucional à gestão tributária da propriedade predial e urbana. Estamos falando, primeiro, da edição da já referida Emenda Constitucional no 29/2000, trazendo uma progressiva alteração no debate envolvendo a possibilidade de progressividade do IPTU, neste particular, fomentado pela perspectiva de crescimento da arrecadação da receita municipal visando angariar maiores recursos aos precários orçamentos locais. Tal alteração veio alcançar, na espécie, as disposições do art. 156, § $1^{\circ}$, da Constituição Federal de 1988, assim redigido:

Art. 156 -

$\S 1^{\circ}$ Sem prejuízo da progressividade no tempo a que se refere o art. $182, \S 4^{\circ}$, inciso II, o imposto previsto no inciso I poderá:

I - ser progressivo em razão do valor do imóvel;

II - ter alíquotas diferentes de acordo com a localização e o uso do imóvel.

Com tal dicção, para nós restou claro que a Emenda Constitucional n ${ }^{\circ}$ 29/00 retirou dos acórdãos proferidos pelo STF as suas eficácias, não mais condicionando a progressividade ao cumprimento da função social da propriedade emoldurado pelo inciso XXII, do art. $5^{\circ}$, ou à aludida

\footnotetext{
${ }^{26}$ BOTELHO, Werther. Da Tributação e sua Destinação. Belo Horizonte: Del Rey, 1999, p. 39.

${ }^{27}$ GRAU, Eros Roberto. A Interpretação do Direito e a Interpretação do Direito Tributário. In: Estudos de Direito Tributário em Homenagem à Memória de Gilberto de Ulhôa Canto. Rio de Janeiro: Forense, 1998, p. 125.
} 
progressividade extrafiscal prevista no art. $182, \S^{\circ}$, autorizando, isto sim, sua imposição para outras possibilidades.

Por óbvio que tal entendimento não se pacificou até os dias de hoje, mas ao menos reabriu o debate sobre tema tão candente, social e politicamente. Veja-se que aqueles doutrinadores que sustentavam a inconstitucionalidade da progressividade do IPTU, após a edição da Emenda Constitucional referida, sustentam que ela desrespeitou os direitos e garantias individuais insculpidos no art. 60, $\$ 4^{\circ}$, IV, da Carta Constitucional, e asseveram que a interferência entre poderes, decorrente de correção legislativa, deve (ou deveria) buscar o equilíbrio necessário à realização do bem da coletividade, posto que visa evitar o arbítrio e o desmando de um Poder em detrimento do outro, afigurando-se a atitude do legislador ao promulgar a emenda como meramente fiscalista, não podendo se sustentar. ${ }^{28}$

O mesmo ocorre, enquanto segundo mecanismo de gestão tributária da propriedade urbana e predial, com a edição do Estatuto da Cidade, Lei Federal $\mathrm{n}^{\mathrm{o}} 10.257$, de 10.07.2001, eis que ela veio fixar as diretrizes do art. 182, da CF/88, dando densidade à idéia de função social da cidade e, no particular, asseverar que:

A política de desenvolvimento urbano, executada pelo Poder Público municipal, conforme diretrizes gerais fixadas em lei, tem por objetivo ordenar o pleno desenvolvimento das funções sociais da cidade e garantir o bem-estar de seus habitantes.

No seu artigo primeiro, parágrafo primeiro, refere explicitamente que, para todos os efeitos, suas normas de ordem pública e interesse social regulam o uso da propriedade urbana em prol do bem coletivo, de segurança e do bem-estar dos cidadãos, bem como do equilíbrio ambiental.

Por tais razões, o Estatuto da Cidade trata o IPTU progressivo com natureza eminentemente sancionatória, no sentido de que se viabiliza quando o proprietário do imóvel não edificado, sub-utilizado ou não utilizado, deixar de promover, após notificado, seu adequado aproveitamento $\left(\operatorname{art.} 5^{\circ}\right)$. Este dispositivo, prevê a possibilidade de lei municipal regular o parcelamento, a edificação ou a utilização compulsórios do solo urbano nas situações anteriormente referidas, tendo como tais os espaços urbanos

\footnotetext{
${ }^{28}$ Conforme texto de ANTONELLI, Leandro Pietro. Emenda Constitucional 29/2000 - Progressividade do IPTU. Revista Tributária e de Finanças Públicas, São Paulo, ano 9, n. 39, jul./ago. 2000, p. 97-115.
} 
cujo aproveitamento seja inferior ao mínimo definido no plano diretor ou em legislação dele decorrente, ou aquele utilizado em desacordo com a legislação urbanística ou ambiental, ou ainda aqueles efetivamente não aproveitados para fim algum.

Uma vez identificados estes imóveis nas configurações dadas pela lei municipal, é que se pode pensar as possibilidades de incidência do IPTU progressivo, aqui compreendido como o que possui alíquotas que aumentam conforme critérios normativamente estabelecidos, de forma que certos contribuintes - possuidores de imóveis que se enquadrem nos termos referidos pelo art. $5^{\circ}$ do Estatuto da Cidade e pela Lei municipal - respondam pelo imposto com uma alíquota mais alta, o que implica pagamento também diferido a maior. ${ }^{29}$

Todos estes indicadores ampliam, de forma até retrospectiva, o enfrentamento da matéria em termos de políticas públicas locais vigentes, por exemplo, na cidade de Porto Alegre, aqui tomada apenas como estudo de caso demonstrativo da pertinência do debate. Passamos à sua breve análise.

\section{A experiência do Município de Porto Alegre na Gestão do IPTU: aspectos de legalidade}

O Município de Porto Alegre, capital do Estado do Rio Grande do Sul, Brasil, ao editar a Lei Complementar $n^{\circ}$ 07/73, com a redação que lhe deu a Lei Complementar no 212/89, estabeleceu o IPTU vinculado a alíquotas diferidas, consoante o valor venal dos imóveis alcançados pelo tributo (art. $5^{\circ}$, da norma citada). Tal fato tem sido entendido pelo Tribunal de Justiça do Estado do Rio Grande do Sul, e mesmo pelo Supremo Tribunal Federal - STF, como violador do princípio da capacidade contributiva em face dos impostos tidos como reais, caso do IPTU, nos termos do art. 145, $\S 1^{\circ}$, da $\mathrm{CF} / 88$. Ademais, em tal linha reflexiva, a eventual progressividade do IPTU se destinaria à res, e não ao contribuinte em sua capacidade de contribuir, como mecanismo de política extrafiscal, visando à função social da propriedade, temas que já referimos anteriormente.

\footnotetext{
A despeito destes posicionamentos, temos nos postado em direção ${ }^{29}$ Por óbvio que dada a discórdia e resistência de setores imobiliários especulativos existentes em todo o país, o instituto é deveras polêmico, contando com centros de oposição espargidos em vários níveis do cenário político brasileiro, a começar pela discussão sobre as formalidades que devem delimitar bem o descumprimento das obrigações inscritas no art. 5, prazos, devido processo legal, garantias processuais constitucionais, etc. Neste sentido, a Emenda Constitucional no 29/2000, alterando a redação do art. 156, da CF/88, prevê a possibilidade do IPTU progressivo em razão do imóvel, sem prejuízo do disposto no art. 182, \$4$^{\circ}$, II, do mesmo Estatuto.
}

A \& C R. de Dir. Administrativo e Constitucional, Belo Horizonte, ano 4, n. 16, p. 107-123, abr./jun. 2004 
oposta em relação à matéria, entendendo que a referida legislação municipal não previu progressividade extrafiscal alguma para o IPTU, mas tão somente graduação de alíquotas consoante o valor venal dos imóveis, consideradas as suas localizações e utilizações, perfeitamente descritas na legislação atacada.

Quanto ao STF, tenho que ele, até agora e com divisão de convencimentos, declarou a inconstitucionalidade de dispositivo municipal que previu alíquotas progressivas do IPTU para os fins de finalidades meramente fiscais, e não extrafiscais. ${ }^{30}$ Ademais, gize-se que tal decisão do STF, nos autos do Recurso Extraordinário no $179.273-R S$, está a produzir efeitos em relação às partes daquela ação, sem efeitos erga omnes, pois inexiste declaração de inconstitucionalidade de norma municipal em face da Constituição Federal, na forma direta.

Assim, tem razão a municipalidade quando sustenta a tese de que alíquotas diferentes para determinadas classes de imóveis nada têm de relação com a progressividade tributária, instrumento que faz a tributação graduar de acordo com o valor do imóvel, para fins de IPTU. Tais alíquotas, na verdade, têm critérios objetivos de justificação e mensuração, envolvendo localização e utilização dadas aos imóveis. Um exemplo material disto é exatamente a forma eleita à divisão fiscal do território municipal, relacionada com a ocupação do espaço urbano da cidade e não com o valor venal dos imóveis, i.é., ela está fundada pela forma de inserção (ocupacional e de localização) dos imóveis na cartografia urbana existente, e daqui decorre a natureza seletiva e não progressiva do tributo.

Por derradeiro, a Emenda Constitucional no 29/2000, veio dimensionar a possibilidade de progressividade do IPTU, quando assevera em seu art. $3^{\circ}$, alterando a redação do $\S 1^{\circ}$, do art. 156, da CF/88, que o IPTU pode ser progressivo em razão do valor do imóvel, bem como ter alíquotas diferentes de acordo com a localização e uso do imóvel.

Em meio a esta discussão, a municipalidade de Porto Alegre encaminhou e se viram aprovadas as Leis Complementares no 437 e 438/2000, para o fim específico de instituir alíquotas únicas para imóveis prediais residenciais e não residenciais, novos valores do metro quadrado de terrenos e construções a serem utilizados no cálculo do imposto, e o denominado limitador genérico do imposto, sem afetar, contudo, as alíquotas atinentes aos imóveis não edificados.

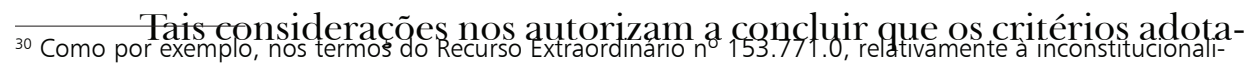
dade da lei no município de Belo Horizonte.

A \& C R. de Dir. Administrativo e Constitucional, Belo Horizonte, ano 4, n. 16, p. 107-123, abr./jun. 2004 
dos pela municipalidade não violam em nada as disposições constitucionais e infraconstitucionais referidas anteriormente, antes disto, vai ao encontro delas, eis que respeita os critérios constitucionais estabelecidos para políticas tributárias locais, e contribui no processo de efetivação da função social da cidade.

\section{Considerações finais}

Pelo que vimos ao longo deste trabalho, restou claro que a partir da Constituição de 1988, o sistema jurídico brasileiro somente protege a propriedade que cumpra à sua função social, ou seja, que aproveite, ainda que de forma indireta, à sociedade como um todo. Significa dizer, neste particular que tanto faz se a propriedade em tela dispõe de função individual, ou não, distinção feita por Eros Grau. ${ }^{31}$ Mesmo a propriedade com função precipuamente individual (como o imóvel residencial) deve cumprir uma função social, na medida em que é efetivamente utilizada para seu fim (habitação), colaborando, assim, com o bem-estar geral.

Uma parte da tradicional doutrina civilista no país desde há muito destacava tal particularidade da propriedade, à época como uma crítica pontual às estruturas sociais e patrimoniais existentes:

A resposta segundo a qual a função social da propriedade é antes uma concepção com eficácia autônoma e incidência direta no próprio direito consente elevá-la à dignidade de um princípio que deve ser observado pelo intérprete, tal como sucede em outros campos do direito, civil, como princípio da boa fé nos contratos. É verdade que assim considerada se torna uma noção vaga, que todavia não é inútil na medida em que inspira a interpretação da atividade do proprietário. Nessa ótica, a ação do juiz substitui a do legislador, do Congresso ou da Administração Pública. O comportamento profissional do magistrado passa a ser, no particular, uma "ação de invenção e de adaptação", como se exprime LANVERSIN 54 definindo a ação pretoriana como um meio de realizar a modernização do direito. ${ }^{32}$

Em termos tributários, objeto específico deste ensaio, não é possível aceitarmos a tese de que a propriedade não se presta ao alcance de uma política fiscal e extrafiscal vinculada aos princípios constitucionais e aos direitos humanos e fundamentais. Em outras palavras, queremos insistir na tese de que, sempre que possível, os impostos terão caráter pessoal (pois

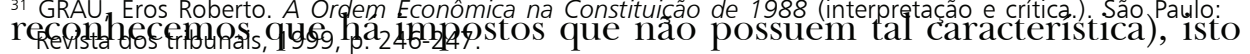

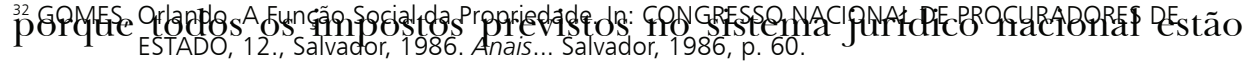

A \& C R. de Dir. Administrativo e Constitucional, Belo Horizonte, ano 4, n. 16, p. 107-123, abr./jun. 2004 
sujeitos ao princípio da capacidade contributiva, mesmo os que não tenham caráter pessoal.

Filiando-nos ao pensamento lúcido do Ministro Carlos Velloso, temos que, em termos constitucionais, é possível distinguir a progressividade fiscal estabelecida no arts. $145, \S 1^{\circ} ; 156, \S 1^{\circ}$, da Carta Política de 1988, da progressividade-sanção inscrita no art. $182, \S 4^{\circ}$, II, e isto porque a progressividade-sanção, neste dispositivo inscrita, constitui instrumento de realização da política de desenvolvimento urbano das cidades brasileiras (ex vi o art. 182), que tem no plano diretor aprovado pela Câmara Municipal, obrigatório para cidades com mais de vinte mil habitantes, o seu instrumento básico. O conceito, portanto, de função social, nesse contexto, está relacionado com a política de desenvolvimento urbano e o seu não atendimento facultará ao poder público municipal a adoção das medidas postas nos incisos I a III, do $\S 4^{\circ}$, do art. 182, especificamente para o solo urbano não edificado, subutilizado ou não utilizado, e uma delas é a progressividade no tempo (art. 182, $\S 4^{\circ}$, II). ${ }^{33}$

Enfatiza o autor ainda que:

Tem-se, no caso do art. 182, $\S 4^{\circ}$, II, a progressividade extrafiscal, distinta da progressividade fiscal (art. $145, \S 1^{\circ}$, art. $\left.156, \S 1^{\circ}\right)$. Noutras palavras, a progressividade no tempo extrafiscal, inscrita no art. 182, §4 ${ }^{\circ}$, II, da Constituição, não impede a realização da progressividade fiscal $\left(\operatorname{art} .145, \S 1^{\circ}\right.$, art. $\left.156, \S 1^{\circ}\right) .^{34}$

Na mesma direção vai Geraldo Ataliba, quando assevera que o art. 182 (especialmente seu $\S^{\circ}$, II), prevê uma disciplina extrafiscal; consiste esta extrafiscalidade no uso de instrumentos tributários para obtenção de finalidades não arrecadatórias, mas estimulantes, indutoras ou coibidoras de comportamentos, tendo em vista outros fins, a realização de outros valores constitucionalmente consagrados (no caso, valores urbanísticos). Para o autor, a partir deste cenário, não implica censura à progressividade projetada, como o foi, com finalidades puramente fiscais, tendo em vista a melhor e mais perfeita adequação à capacidade contributiva dos proprietários, no clima de solidariedade social que a Constituição de 1988 instaurou. ${ }^{35}$

De outro lado, para uma leitura mais sistêmica do ordenamento jurídico próprio à espécie, podemos sustentar também que é a lógica organizacional estruturante da Constituição que conspira nesta direção, eis

\footnotetext{
33 VELLOSO, Carlos Mário da Silva. Questões Tributárias Atuais no Supremo Tribunal Federal. Revista de Estudos Tributários, São Paulo, n. 7, 1999, p. 5.

34 Op. cit., p. 6.
}

A \& C R. de Dir. Administrativo e Constitucional, Belo Horizonte, ano 4, n. 16, p. 107-123, abr.jun. 2004 
que os dispositivos constitucionais anteriormente referidos (art. 156, $\S 1^{\circ} \mathrm{e}$ $\left.184, \S 4^{\circ}, \mathrm{II}\right)$ encontram-se em locais distintos: o primeiro, no capítulo do Sistema Tributário Nacional, e o segundo, no capítulo que trata da política urbana e não de tributos. Isto já seria indicador de que as progressividades devem receber tratamentos diferentes, cada qual levando em conta os objetivos que perseguem o sistema como um todo. ${ }^{36}$

Por todas estas razões é que concluímos, com Sacha Calmon, que, a partir da Constituição Brasileira de 1988, o IPTU pode ser progressivo em face de duas variáveis: (a) A variável da política urbana, cujo fundamento constitucional tem sede nas disposições referidas anteriormente, em prol da ordenação urbanística das municipalidades (progressividade extrafiscal no tempo); e (b) A variável da capacidade do contribuinte, decorrente das disposições do art. $145, \S 1^{\circ}$, da CF. Esta última progressividade não cresce ano a ano no funil do tempo, como a anterior. Nesta, o imposto em si é estruturado com alíquotas progressivas e, pois, menores e maiores no espelho do tempo (alíquotas existentes num mesmo instante). ${ }^{37}$ No primeiro caso, a meta optada é remover obstáculos ao plano diretor. Na segunda, procura-se, em função da pessoa do proprietário (imóveis mais valorizados, número de imóveis possuídos, tamanho da propriedade imóvel, etc.) fazer atuar o princípio da capacidade contributiva.

\section{Referências}

ANTONELLI, Leandro Pietro. Emenda Constitucional 29/2000 - Progressividade do IPTU. Revista Tributária e de Finanças Públicas, São Paulo, ano 9, n. 39, jul./ago. 2000. p. 97-115.

ATALIBA, Geraldo. Derechos Humanos y Tributación. In: PRIMERAS JORNADAS INTERNACIONALES DE TRIBUTACIÓN Y DERECHOS HUMANOS. Lima: Asociación Internacional de Tributación y Derechos Humanos, 1990.

ATALIBA, Geraldo. IPTU - Progressividade. Revista de Direito Tributário, São Paulo, v. 93, 2000.

BALEEIRO, Aliomar. Direito Tributário Brasileiro. Rio de Janeiro: Forense, 1999.

BALEEIRO, Aliomar. Limitações Constitucionais ao Poder de Tributar. Atual. por Mizabel Abreu Machado Derzi. Rio de Janeiro: Forense, 1997.

BARBON, Sandra Lopez. Do IPTU. Belo Horizonte: Del Rey, 1995.

BOTELHO, Werther. Da Tributação e sua Destinação. Belo Horizonte: Del Rey, 1999.

BUFFON, Marciano. O Princípio da Progressividade Tributária na Constituição Federal de 1988. São Paulo: Memória Jurídica, 2003.

CARRAZA, Roque Antonio. Curso de Direito Constitucional Tributário. São Paulo: Malheiros,

\footnotetext{
${ }_{35}$ ATALIBA, Geraldo. IPTU - Progressividade. Revista de Direito Tributário, São Paulo, v. 93, 2000, p. 233.

${ }^{36}$ Ver neste sentido o excelente trabalho de BARBON, Sandra Lopez. Do IPTU. Belo Horizonte: Del Rey, 1995.

${ }^{37}$ COELHO, Sacha Calmon Navarro. Comentários à Constituição de 1988: sistema tributário. Rio de Janeiro: Forense, 2000, p. 253.
}

A \& C R. de Dir. Administrativo e Constitucional, Belo Horizonte, ano 4, n. 16, p. 107-123, abr./jun. 2004 
2001.

CARVAlHO, Paulo de Barros. Curso de Direito Tributário. São Paulo: Saraiva, 2001.

COELHO, Sacha Calmon Navarro. Comentários à Constituição de 1988: sistema tributário. Rio de Janeiro: Forense, 2000.

CONTI, José Maurício. Princípios Tributários da Capacidade Contributiva e da Progressividade. São Paulo: Dialética, 1997.

COSTA, Regina Helena. Princípio da Capacidade Contributiva. São Paulo: Malheiros, 1998.

DELGADO, José Augusto. A Interpretação Contemporânea do Direito Tributário e os Princípios da Valorização da Dignidade Humana e da Cidadania. In: Tributos e Direitos Fundamentais. São Paulo: Dialética, 2004.

DERZI, Mizabel; COELHO, Sacha Calmon Navarro. Do Imposto sobre a Propriedade Predial e Territorial Urbana. São Paulo: Saraiva, 1982.

FURLAN, Valéria C. P. Imposto Predial e Territorial Urbano. São Paulo: Malheiros, 1998. ICHIHARA, Yoshiaki. O Princípio da Progressividade e suas Implicações no IPTU. Revista de Direito Tributário, São Paulo, n. 81, 2000.

GOMES, Orlando. A Função Social da Propriedade. In: CONGRESSO NACIONAL DE PROCURADORES DE ESTADO, 12., Salvador. Anais... Salvador, 1986.

GRAU, Eros Roberto. A Interpretação do Direito e a Interpretação do Direito Tributário. In: Estudos de Direito Tributário em Homenagem à Memória de Gilberto de Ulhôa Canto. Rio de Janeiro: Forense, 1998.

GRAU, Eros Roberto. A Ordem Econômica na Constituição de 1988 (interpretação e crítica.). São Paulo: Revista dos Tribunais, 1999.

GRUPENMACHER, Betina Treiger. Tributação e Direitos Fundamentais. In: Tributos $e$ Direitos Fundamentais. São Paulo: Dialética, 2004.

MACHADO, Hugo de Brito. Curso de Direito Tributário. São Paulo: Malheiros, 2001.

MORAES, Bernardo Ribeiro. Compêndio de Direito Tributário. Rio de Janeiro: Forense, 2002.

NASCIMENTO, Carlos Valder. A Questão da Progressividade do IPTU. Revista dos Tribunais, ano 8, n. 34, p. 69-80.

NUNES, Vidal Serrano. Direito Constitucional Tributário. São Paulo: Didática Paulista, 1990.

VELLOSO, Carlos Mário da Silva. Questões Tributárias Atuais no Supremo Tribunal Federal. Revista de Estudos Tributários, São Paulo, n. 7, 1999.

XAVIER, Alberto. Os Princípios da Legalidade e da Tipicidade da Tributação. São Paulo: Revista dos Tribunais, 1998 